\title{
Two Rare Causes of Hepatitis: Fascioliasis and Brucellosis
}

\author{
Iki Nadir Hepatit Sebebi: Fasioliazis ve Brusellozis
}

\author{
Uğur ÖNAL11, Tansu YAMAZHAN1, Hüsnü PULLUKÇU1', Meltem TAŞBAKAN1, Sadık TAMSEL2, \\ Derya DIRIM ERDOĞAN33, Metin KORKMAZ33, Oğuz Reşat SIPAHI'1
}

${ }^{1}$ Ege University Faculty of Medicine, Department of Infectious Diseases and Clinical Microbiology, Izmir, Turkey

2Ege University Faculty of Medicine, Department of Radiology, Izmir, Turkey

${ }^{3}$ Ege University Faculty of Medicine, Department of Parasitology, Izmir, Turkey

\begin{abstract}
Brucellosis and fascioliasis are zoonoses which induce different type of cell-mediated immune responses and rarely cause hepatitis with together. Brucellosis induces Thelper type 1 (Th1) immune response whereas Fasciola hepatica induces T helper type 2 (Th2) immune. It may be speculated that chronic fascioliasis can predispose to brucellosis by suppression of Th1 response against brucellosis. In this paper, we present a patient who was diagnosed with brucellosis as well as chronic fasciolasis on the basis of parasite that was seen incidentally during the abdomen ultrasonography. To our knowledge, this case is one of the few cases in the literature that showing the co-infection of the liver by both fascioliasis and brucellosis.

Keywords: Brucellosis, fascioliasis, hepatitis, treatment
\end{abstract}

\section{ÖZ}

Brusellozis ve fasioliazis farklı tiplerde hücresel bağışıklık yanıtını uyaran zoonozlar olup birlikte nadiren hepatit tablosuna neden olurlar. Brusellozis, T yardımcı hücre tip 1 (Th1) ile bağışıklık yanıını uyarırken Fasciola hepatica ise T yardımcı hücre tip 2 (Th2) ile uyarır. Th1 yanıtını baskılaması dolayısıyla kronik fasciola enfeksiyonun brusellozise yatkınlık yarattı̆ı̆ düşünülebilir. Bu yazıda brusellozis tanısına ek olarak batın ultrasonografi ile rastlantısal olarak görülen parazit dolayısıyla kronik fasiolazis tanısı alan bir olgu sunulmaktadır. Literatürde bildiğimiz kadarıyla olgumuz fasiolazis ve brusellozis ile eş zamanlı enfekte olan nadir olgular arasında yer almaktadır.

Anahtar Kelimeler: Bruselloz, fasioliazis, hepatit, tedavi

Önal U, Yamazhan T, Pullukçu H, Taşbakan M, Tamsel S, Dirim Erdoğan D, Korkmaz M, Sipahi OR. Two Rare Causes of Hepatitis: Fascioliasis and Brucellosis. Viral Hepat J. 2017;23:76-79.

\section{Introduction}

Fascioliasis is a zoonotic infection caused by Fasciola hepatica or Fasciola gigantica. Clinical forms of infection include the acute (liver) phase and chronic (biliary) phase. Infection in humans mainly occurs through ingesting uncooked watercress or other fresh aquatic vegetations containing metacercariae, which excystin the duodenum and migrate to the liver parenchyma, where they develop into adult forms (1). On the other hand, brucellosis is a multisystem disease that can mimic many diseases and obscure the diagnosis of other infections (2). Brucellosis and fascioliasis are zoonoses inducing different type of cell-mediated immune responses. Brucellosis and other intracellular bacterial pathogens together with viruses induce $T$ helper type 1 (Th1) immune response via cytokines such as interleukin (IL)-12 and IL-18 whereas helminths like $F$. hepatica induce T helper type 2 (Th2) immune response and increase the levels of immunoglobulin (Ig) $E$ levels eosinophils $(3,4)$.

\section{Case}

A 43-year-old female patient was hospitalized at another center three weeks ago because of fever with shaking chills, malaise, nausea, vomiting, epigastric pain, headache, and darkening of the urine color for the past ten days. The patient was discharged from the hospital with doxycycline and rifampin for brucellosis confirmed by the blood cultures positive for Brucella spp. After using these medications for only one week, the patient was admitted to our clinic with the same complaints. 
She had a history of raising livestock; ingestion of fresh milk, raw cheese and also watercress near the stream of that region. She had moved from Eastern Anatolia with her family three months ago. Physical examination revealed epigastric tenderness only and all the other vital signs were normal. Laboratory findings were as follows: hemoglobin: $8.9 \mathrm{~g} / \mathrm{dL}$, hematocrit: $28.6 \%$, leukocytes: 3900/ $\mathrm{mm}^{3}$, eosinophils: $0.5 \%$, aspartate transaminase: $85 \mathrm{U} / \mathrm{L}$, alanine transaminase: $114 \mathrm{U} / \mathrm{L}$, alkaline phosphatase: $533 \mathrm{U} / \mathrm{L}$, gamma-glutamyl transpeptidase: $423 \mathrm{U} / \mathrm{L}$, total bilirubin: 2.19 (direct bilirubin: 1.71$) \mathrm{mg} / \mathrm{dL}$, rose Bengal: $(+)$, and standard wright: 1/160 positive. Due to epigastric tenderness, we performed abdominal ultrasonography which revealed linear mobile structures $15 \mathrm{~mm}$ in length considered live parasites within the gallbladder (Figures 1, 2). After this result, in-house serological tests were performed for toxocariasis, fascioliasis, trichinellosis and cystic echinococcosis (CE). Serological findings were as follows: anti-F. hepatica ELISA IgG: positive, anti-Echinococcus granulosus ELISA IgG: positive (1/640), and E. granulosus indirect hemagglutination (IHA): positive (1/640). Parasitological stool tests were performed on three consecutive days and no parasites were detected. Thoracoabdominal computed tomography (CT) was performed for hydatid cyst and there was no radiological sign of echinococcosis. CT revealed a subcapsular hypodense lesion at the level of segment 6 in the liver and $1.2 \mathrm{~cm}$ diameter heterogeneity within the gallbladder. Since there was no clinical and radiological finding

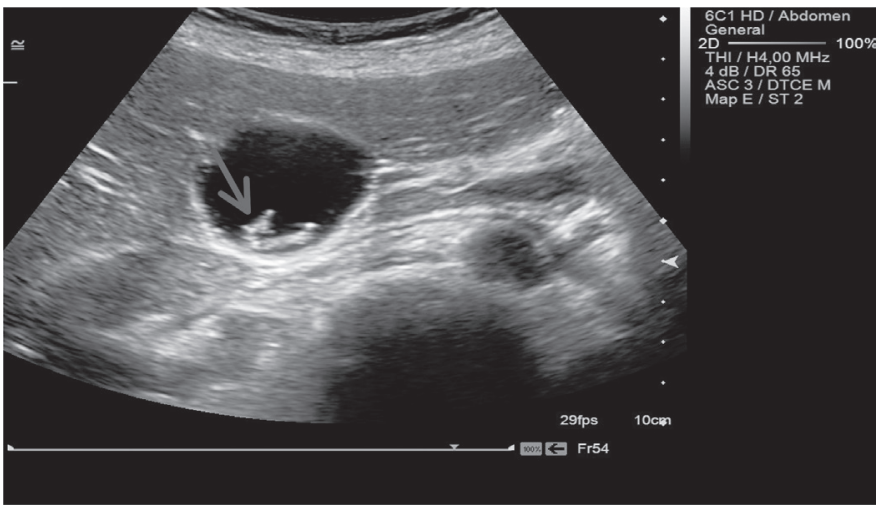

Figure 1. Ultrasonographic image of gall bladder

* Red arrow shows that lineer mobile structures $15.4 \mathrm{~mm}$ in length considered as live parasites within the gallbladder

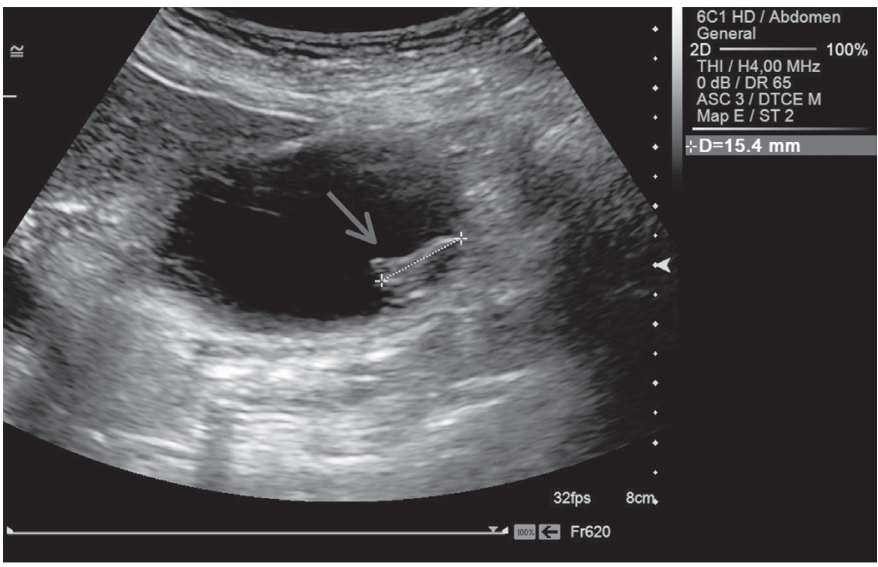

Figure 2. Ultrasonographic image of gall bladder

* Red arrow shows that lineer mobile structures $15.4 \mathrm{~mm}$ in length considered as live parasites within the gallbladder in ultrasonography of hydatid disease, the serologic positivity was thought to be a cross reaction.

For the treatment of brucellosis, doxycycline $100 \mathrm{mg} \mathrm{q12h}$ (p.o) and rifampin $600 \mathrm{mg}$ q24h (p.o) for six weeks and gentamycin $160 \mathrm{mg}$ q24h (i.m) for two weeks were prescribed. Triclabendazol was also started (10 mg/kg/d; 2 doses, q12h). Screening of three family members was done and one of the family members was found to have fascioliasis (anti-F. hepatica ELISA IgG: positive) and treated with triclabendazol as well. Anti-F. hepatica ELISA IgG was detected as positive in the patient's control serum eight month after triclabendazol treatment.

\section{Discussion}

Brucellosis is an endemic infection in Turkey (2). Brucellosis gives rise to many hepatic manifestations with different patterns. Clinical hepatitis in brucellosis is relatively rare. Buzgan et al. (5) reported that out of 1028 brucellosis patients, elevated liver transaminase levels were seen in $24.8 \%$, whereas hepatic involvement was seen in only 28 (2.7\%) patients. Our case also presented as hepatitis with elevated liver transaminase levels.

Brucella antigens induce the pathway of Th1 immune response via cytokines, and Th1 immune response is crucial for recovery from Brucella infection. Inadequate response of the Th1 immune system and anergy have been described in patients with chronic brucellosis which is associated with poor outcome (3). Brady et al. (4) described suppression of the Bordetella pertussis-specific Th1 response and late bacterial clearance from the lungs in $F$. hepatica coinfected mice. Similar to our case, probably chronic fascioliasis predisposed to brucellosis by the suppression of Th1 response against brucellosis.

F. hepatica has a worldwide distribution, especially in parts of America, China, Europe, Africa, and the Middle East with an estimated 2.4-17 million people infected throughout the world (6). Karahocagil et al. (7) reported a familial outbreak of fascioliasis in Eastern Anatolia similar to our case, all the 24 patients who were diagnosed with fascioliasis had a history of watercress ingestion, lack of appetite, fatigue, malaise and abdominal pain.

The diagnosis of fascioliasis is based on identifying eggs in stool and adult worms in endoscopic or surgical specimens. However, egg detection in faeces with coprological examination is not useful during the acute phase of the disease and has low sensitivity during the chronic phase. In contrast, antibody detection in serum via ELISA method is usually used for the diagnosis of acute infections with high sensitivity and can be used in addition to fecal examination for the latent and chronic infections. Imaging can be an adjunctive tool. Negative stool examinations do not rule out the diagnosis. The eggs are released intermittently from the bile ducts, thus, stool samples may not contain eggs even in infected patients. Therefore it is necessary to perform consecutive analyses of samples $(8,9)$.

Sheep are very good hosts for F. hepatica and tend to shed a large number of eggs (up to 20.000 eggs per day). Adult liver fluke produce about 200 times more eggs in sheep than in other species. This makes sheep a very good host for liver fluke (10). Humans are not the primary host for F. hepatica and tend to shed a few number of eggs. Among Bolivian children, eggs in stools ranged from 24 to 5064 epg (geometric mean: 201-309 epg) (11). 
A prospective study showed a geometric mean level in stools of 233 epg (range: 25-2100 epg) in Porto/Portugal (12). The intensity of egg dischargesis higher in children than in adults (24-4400 epg vs. 144-864 epg) in human endemic area (11). In the presented case, parasitological stool tests were performed on three consecutive days and were found to be negative for fascioliasis. Hence, the diagnosis was made by serological and imaging techniques.

Specific findings on ultrasonography are very helpful in the diagnosis of fascioliasis. Sezgin et al. (12) reported that one of the most common findings was dilatations in the biliary duct with thickening in the duct wall, peripheral hypoechoic nodular lesions, and hyperechoic nonshadowing images filling the common bile duct. Flukes within the gallbladder as in our case and lymphadenopathies were the other important findings.

E. granulosus has a large geographical distribution throughout the world and is a major health problem in many parts of the Mediterranean region, Africa, China and South America. Between the years 2001 and 2005, several hospital and Ministry of Health archives have recorded 14.789 cases of human CE in Turkey (13). The diagnosis of CE is mainly based on radiological and immunological methods. Specificity of the serological tests for CE is limited due to cross-reactions with other helminth diseases, malignancies and liver cirrhosis. When there is no clinical and radiological finding of hydatid disease, serologic positivity for CE is considered as a cross reaction (14). Kaya et al. (15) reported that indirect immunofluorescence assay (IFA) for E. granulosus was positive in $59 \%$ (13 of 22 ) of patients with fascioliasis and $8.3 \%$ (2 of 24) of healthy people. The titers of antibodies were $1 / 100$ in six and 1/320 in seven patients with fascioliasis. In the presented case, serological findings using in-house assays were: anti-F. hepatica ELISA IgG: positive, anti-E. granulosus ELISA IgG: positive (1/640), and E.granulosus IHA: positive (1/640). Since there was no clinical and radiological finding of hydatid disease, E. granulosus positivity was thought to be a cross reaction. In addition, serologic testing for fasciolasis may be useful to rule out this parasitosis in patients from endemic areas (16).

Triclabendazole, a benzimidazole derivative, the only treatment recommended by World Health Organization against fascioliasis, is active against both mature and immature form of parasites, thus, it can be used during the acute and chronic phases. Treatment success is high whereas adverse reactions are usually temporary and mild. The recommended dose of the regimen is $10 \mathrm{mg} / \mathrm{kg}$ as a single dose. In clinical practice, if a failure of treatment happens, the dose can be increased to $20 \mathrm{mg} / \mathrm{kg}$ in two divided doses $12-24$ hours apart $(17,18)$. The presented case was treated with triclabendazol (10 mg/kg/d; 2 doses, q12h).

In relatives of index cases, human fascioliasis can be found in high rates and because of this reason, screening of family members is very important. Eating raw vegetables such as watercress is an important risk factor for families who may acquire the infection in endemic areas. It is recommended that patients presenting abdominal pain and low to high eosinophile levels, who have recently visited an endemic area for F. hepatica, should be investigated carefully in order to rule out fascioliasis and, the family members also should be searched (19). In the presented case, screening of three family members was done and one of the family members had fascioliasis detected by serological investigation.
Deveci et al. (20) from Dicle University, Diyarbakir, Turkey have reported a case of fasciola and Brucella coinfection in a 39-year-old male patient who was diagnosed via serological and radiological investigations, as in our case.

In the literature, this is one of the rare reported cases from Turkey. To our knowledge, this is one of the few reported cases in the literature that showing the co-infection of the liver by both fascioliasis and brucellosis leading to hepatitis.

\section{Ethics \\ Informed Consent: It was not taken. \\ Peer-review: Externally peer-reviewed.}

\section{Authorship Contributions}

Surgical and Medical Practices: S.T., D.D.E, M.K., Concept: H.P., M.T., Design: O.R.S., Data Collection or Processing: U.Ö., Analysis or Interpretation: U.Ö., T.Y., Literature Search: U.Ö., Writing: U.Ö.

Conflict of Interest: No conflict of interest was declared by the authors.

Financial Disclosure: The authors declared that this study received no financial support.

\section{References}

1. Mas-Coma S, Bargues MD, Valero MA. Fascioliasis and other plant-borne trematode zoonoses. Int J Parasitol. 2005;35:12551278.

2. Tasbakan MI, Yamazhan T, Gokengin D, Arda B, Sertpolat M, Ulusoy S, Ertem E, Demir S. Brucellosis: a retrospective evaluation. Trop Doct. 2003;33:151-153.

3. Skendros P, Boura P. Immunity to brucellosis. Rev Sci Tech. 2013;32:137-147

4. Brady MT, O'Neill SM, Dalton JP, Mills KH. Fasciola hepatica suppresses a protective Th1 response against Bordetella pertussis. Infect Immun. 1999;67:5372-5378.

5. Buzgan T, Karahocagil MK, Irmak H, Baran Al, Karsen H, Evirgen $\mathrm{O}$, Akdeniz H. Clinical manifestations and complications in 1028 cases of brucellosis: a retrospective evaluation and review of the literature. Int J Infect Dis. 2010;14:e469-478.

6. Mas-Coma S, Valero MA, Bargues MD. Chapter 2. Fasciola, lymnaeids and human fascioliasis, with a global overview on disease transmission, epidemiology, evolutionary genetics, molecular epidemiology and control. Adv Parasitol. 2009;69:41146.

7. Karahocagil MK, Akdeniz H, Sunnetcioglu M, Cicek M, Mete R, Akman N, Ceylan E, Karsen H, Yapici K. A familial outbreak of fascioliasis in Eastern Anatolia: a report with review of literature. Acta Trop. 2011;118:177-183.

8. Caban-Hernandez K, Gaudier JF, Ruiz-Jimenez C, Espino AM. Development of two antibody detection enzyme-linked immunosorbent assays for serodiagnosis of human chronic fascioliasis. J Clin Microbiol. 2014;52:766-772.

9. Saba R, Korkmaz M, Inan D, Mamikoglu L, Turhan O, Gunseren F, Cevikol C, Kabaalioğlu A. Human fascioliasis. Clin Microbiol Infect. 2004; 10:385-387.

10. Palmer D. Detection of Trematode Eggs and Eimeria Leuckarti Sedimentation Method (Fest) - Faecal Samples2013 04.06.2015 [cited 2015. Available from: https://www.agric.wa.gov.au/sites/ gateway/files/DAFWA \% 20 approved $\% 2$ fluke $\% 20$ egg $\% 20$ sedimentation\%20test\%20(FEST).pdf.

11. Mas-Coma MS, Esteban JG, Bargues MD. Epidemiology of human fascioliasis: a review and proposed new classification. Bull World Health Organ. 1999;77:340-346. 
12. Sezgin O, Altintas E, Disibeyaz S, Saritas U, Sahin B. Hepatobiliary fascioliasis: clinical and radiologic features and endoscopic management. J Clin Gastroenterol. 2004;38:285-291.

13. Sakru N, Korkmaz M, Demirci M, Kuman A, Ok UZ. Fasciola hepatica infection in echinococcosis suspected cases. Turkiye Parazitol Derg. 2011;35:77-80.

14. Kilimcioglu AA, Girginkardesler N, Korkmaz M, Ozkol M, Duzgun F, Ostan I, Pabuşcu Y, Dinç G, Ok UZ. A mass screening survey of cystic echinococcosis by ultrasonography, Western blotting, and ELISA among university students in Manisa, Turkey. Acta Trop. 2013:128:578-583.

15. Kaya M, Bestas R, Girgin S, Cicek M, Kaplan MA. Increased antiEchinococcus granulosus antibody positivity in Fasciola hepatica infection. Turk J Gastroenterol. 2012;23:339-343.

16. Kaya M, Bestas R, Cicek M, Onder A, Kaplan MA. The value of micro-ELISA test in the diagnosis of Fasciola hepatica infection. Turkiye Parazitol Derg. 2013;37:23-27.
17. Hughes AJ, Spithill TW, Smith RE, Boutlis CS, Johnson PD. Human fasciolosis acquired in an Australian urban setting: Med $J$ Aust. 2003;178:244-245.

18. WHO. Fascioliasis diagnosis, treatment and control strategy. Fascioliasis [Internet]. 2015 04.06.2015 [cited 2015. Available from: http://www.who.int/foodborne_trematode_infections/ fascioliasis/fascioliasis_diagnosis/en/.

19. Marcos L, Maco V, Terashima A, Samalvides F, Espinoza JR, Gotuzzo E. Fascioliasis in relatives of patients with Fasciola hepatica infection in Peru. Rev Inst Med Trop Sao Paulo. 2005;47:219-222.

20. Deveci Ö, Aslan E, Tekin A, Toka Özer T, Tekin R, Bozkurt F, Çetinçakmak MG. Fascioliasis and brucellosis in same patient. Turkiye Parazitol Derg. 2014;38:197-200 